\title{
HOW REPERTOIRES EVOLVE: THE DIFFUSION OF SUICIDE PROTEST IN THE TWENTIETH CENTURY*
}

\author{
Michael Biggs ${ }^{\dagger}$
}

\begin{abstract}
Although "repertoire of contention" is a ubiquitous term in the literature, the concept remains undertheorized and untested. The crucial implication, I argue, is that instances of a tactic belong to one or a few lineages, each radiating from a single invention and comprising a series of adoptions and repetitions. This implication is tested by examining suicide protest: killing oneself, without harming others, for a collective cause. The decline in cruel public punishment and the growth of news media increased the potential utility of this tactic. There were multiple inventions of suicide protest, but only in Japan was there a recognizable lineage in the early twentieth century. The sacrifice of a Vietnamese monk in 1963 created a model, which was adopted in many different countries for varied collective causes. Almost all subsequent acts can be traced — directly or indirectly — back to this origin.
\end{abstract}

Protest tactics are "learned cultural creations," as Tilly (1995: 42) emphasizes. People making claims against powerful adversaries almost always select a tactic from their existing "repertoire," a small subset of the set of all possible tactics. Tilly $(1977,1995,2008)$ and others (e.g., Tarrow 1998) show how the repertoire of contention in Western Europe and North America was transformed in the late eighteenth and early nineteenth centuries, with the emergence of tactics like the public meeting and the demonstration. Although the concept of repertoire has become ubiquitous, Tilly (2008: xiv) notes that "repeated calls for empirical verification, modification, or falsification" have not been answered. Analyses of the diffusion of a particular tactic are generally restricted in time, space, or scope (e.g., Andrews and Biggs 2006; Koopmans and Olzak 2004; McCammon 2003; Myers 2000; Soule 1997). They extend over a short period of years (except Traugott 2010), are confined to a single national society (exceptions include Beissinger 2007; Chabot 2000; McAdam and Rucht 1993), or consider only one species of social movement. Fligstein and McAdam (2011: 23) observe that "the invention of new forms of collective action and their spread has not been well theorized."

To advance understanding of how repertoires evolve, this article examines an extraordinary tactic: suicide protest. I define this by four criteria. First, an individual intentionally kills herself or himself, or at minimum inflicts physical injury likely to cause death. Second, the act is not intended to harm anyone else or to cause material damage. Third, the act is public in either of two senses: performed in a public place, or accompanied by a written declaration addressed to political figures or to the general public. Fourth, the act is committed for a collective cause rather than personal or familial grievances. These criteria serve to differentiate suicide protest from personal suicide, from suicide attacks where the aim is to

\footnotetext{
* Special thanks are due to Diego Gambetta for initially encouraging this project, to fifteen anonymous reviewers for prolonging it, and to Neal Caren for bringing closure. Stacey Boorman, Noah Carl, Jeong Won Choi, Raheel Dhattiwala, and Fei Yan contributed generously to the research, while Kenneth T. Andrews, James Benn, Nancy Bermeo, Eunsu Cho, Michael Finch, Andreas Glaeser, Adam Hradilek, Michael James, Anna Maria Marshall, Avner Offer, Pamela Oliver, Susan Olzak, Darius Rejali, Gerald Schwab, and Wout Ultee offered valuable information and helpful criticism. This research was partly funded by the United Kingdom's Economic and Social Research Council, grant $000-22-0033 z$

Michael Biggs is a Lecturer in the Department of Sociology at the University of Oxford. Please direct all correspondence to michael.biggs@sociology.ox.ac.uk.
} 
harm others, from martyrdom where death is welcomed but not self-inflicted, and from cultic suicide where all members of a group kill themselves. Note that suicide protest implies no particular method of self-killing. It does, however, exclude hunger strikes. Most hunger strikers do not make a commitment to die. ${ }^{1}$ Those who do, use the threat of death to bargain with their adversary. Suicide protest, by contrast, is unconditional: no bargaining is involved.

Compared to familiar tactics such as demonstrations or strikes, suicide protest may seem outlandish (though see Biggs 2005; Grojean 2007, 2008; Kim 2002, 2008; Park 1994, 2004). It is customary to define protest events - as with Tilly's "contentious gathering"-by the copresence of several people. But co-presence is not a necessary feature of tactics such as strikes and boycotts. Conversely, suicide protest is not inherently solitary: it is sometimes performed during a contentious gathering, and it is occasionally undertaken by two or more people together. All these various acts of protest can be counted as collective action in a theoretical sense: someone pays a cost in order to provide a public good from which others will benefit. Suicide protest is the limiting case, as the individual suffers (or risks) the most terrible cost without reaping any personal benefit.

How can suicide function as protest? As we will see, it is a tactic of persuasion. Two kinds of persuasion can be distinguished. The first is addressed to distant audiences, gaining their attention and conveying the gravity of the cause. Voluntary death, as Gambetta (2005: 266-67) observes, "is as strong a signal of the strength of a belief as one can get: only those who hold their beliefs very dear can contemplate making the ultimate sacrifice of dying for a cause." The second kind of persuasion is addressed to those who already adhere to the collective cause, exhorting them to greater efforts. The literature on contentious politics treats mobilization as a matter of discursive framing (Snow et al. 1986), but actions speak louder than words. Investigating South Korea in the late twentieth century, Kim (2008: 549) demonstrates how suicide protest was "used to galvanize collective action . . . in an effort to spawn and invigorate movement activism."

Suicide protest has a major methodological advantage for investigating the repertoire of contention. Because it is so terribly costly, it is exceedingly rare; because of both, it is exceptionally newsworthy. Therefore analysis can be extended in time, space, and scope. A substantive advantage is also worth emphasizing. While the literature on contentious politics concentrates on Western democracies, suicide protest has been most prevalent - and has had the greatest political impact-elsewhere.

\section{THEORY}

Tilly (1977) introduced the concept of the repertoire to capture the subset of tactics employed by people for making claims against powerful others. "At any particular point in history ... they learn only a rather small number of alternative ways to act collectively" (Tilly 1995: 42). To develop this insight further, it is necessary to move beyond vague notions of learning or familiarity. I draw on the theoretical tradition originating in Tarde's Laws of Imitation (1890), now known as the diffusion of innovations (Rogers 1962, 2003) or conceptual selection (Hull 1988). I also focus on individual action, which permits a fundamental distinction between repetition, adoption, and invention. Whether someone has previously practiced a tactic - gone on strike or marched in a demonstration, for instance - is clearly defined and is measured in survey questions. ${ }^{2}$ A typical contentious gathering involves repetition for some and adoption for others. Adoption has many gradations, from joining a performance organized by experienced activists, to borrowing a tactic already used by acquaintances, to adapting a tactic used by dissimilar people under different conditions. Differentiating invention from adoption is more difficult since the boundaries between tactics are sometimes blurred. The difference is conceivably one of degree rather than kind, but it is crucial nonetheless. Tilly's insight can be reformulated in two propositions: repetition is far more likely than adoption; adoption is far 
more likely than invention. These propositions imply the existence of a limited repertoire of tactics within any given social space. Over time, of course, the repertoire evolves.

Let us begin with the invention of a new protest tactic. Invention may borrow from domains of practice that are unrelated to protest. For instance, the barricade was derived in the sixteenth century from chains stretched across a street at night to secure the neighborhood from predation (Traugott 2010). Alternatively, invention may modify an existing tactic, as with the sit-down strike. "New performances arise chiefly through innovation within existing performances," asserts Tilly (2008: 68, also xiii, 4, 154). This conjecture awaits empirical investigation. Sometimes invention appears ex nihilo. In South Korea in 1976, when female strikers awaited attack by riot police, a worker whispered, "[m]en cannot touch undressed women," so hundreds of strikers stripped to their underwear in a desperate attempt to thwart the assault (Koo 2001: 80).

Whatever its ultimate source, invention is sensitive to three conditions: feasibility, legitimacy, and effectiveness. Feasibility refers to structural preconditions (unemployed workers cannot strike, for example) and the costs of a tactic. Legitimacy refers to the sense that the tactic is just and right - from the perspective of those who are going to perform it. Effectiveness refers to the probability that it will be successful, which depends on a myriad of factors -including the tactic's legitimacy in the eyes of others. Effectiveness can be tested only by putting the tactic into practice. To continue the Korean example, the strikers could only guess whether seminudity would protect them. The police were initially dumbfounded, but then attacked anyway. The tactic, at least in this instantiation, proved ineffective.

These three conditions vary across space and change over time. Tilly $(1995,2008)$ draws attention to the large-scale processes of capitalism and state formation which altered the feasibility and effectiveness of tactics. Peasants cannot strike; proletarians can. Sewell (1990) argues that the French Revolution was equally important, because it transformed the basis of legitimacy. Anything that changes these conditions increases the likelihood that a new tactic will be invented in response, albeit with a time lag. Protesters stumble upon new tactics, just as they stumble upon political opportunities (Koopmans 2005: 26). Only in retrospect, after the success of a novel tactic, can protesters - and sociologists - fully understand the changing circumstances that made it feasible, legitimate, and effective.

A tactic may be independently invented more than once, by different people in different social settings. The rate of adoption, however, far exceeds the rate of invention. In most cases, protesters using a tactic for their first time are adopting it from others who have previously used it (the "model"). Adoption presupposes knowledge. Knowledge can be transmitted by personal contact or via news media. The literature emphasizes social networks, even across national boundaries. McAdam and Rucht (1993) identify individuals whose trans-Atlantic travels and friendships linked the German and American student movements in the 1960s, transmitting tactics such as the teach-in. ${ }^{3}$ In a similar fashion, Gandhian ideas became known in Britain and the United States through the efforts of cosmopolitan intellectuals who traveled between India and the West (Scalmer 2011). Research has demonstrated the significance of news media - newspaper, radio, and television - in the diffusion of protest tactics since the 1960s (Andrews and Biggs 2006; Braun 2011; Koopmans and Olzak 2004; Myers 2000).

Knowledge of a novel tactic should be far more likely to inspire adoption if the tactic was effective when used by the model. Evaluating a tactic's effectiveness inherently difficult, though, for protesters no less than for sociologists (Soule 1999). As Tilly (1995) points out, protest in modern societies achieves its effects indirectly, through a long and complicated chain of causality. Two centuries ago, people aggrieved by a brothel in their neighborhood could assemble and ransack the building, a task accomplished within an hour; today they would launch a campaign to persuade politicians to amend the law, which might take years. Any episode of sustained contention invariably involves multiple tactics, and it is difficult to measure the contribution of any one. There is nevertheless a heuristic for evaluating one 
aspect of effectiveness: knowing about a protest tactic from news media also means knowing that it can be effective in gaining media coverage (Koopmans 2004; Koopmans and Olzak 2004).

Knowing about a successful tactic is not sufficient cause to adopt it, of course. Potential protesters must consider it to be feasible, legitimate, and effective in their own circumstances. The probability of a positive judgment diminishes with geographical and social distance. When black college students conducted sit-ins in Greensboro, North Carolina in 1960, it was not difficult for students in nearby cities to judge this novel tactic to be worth adopting. Laborers in Mississippi, by contrast, had good reason to doubt its feasibility and effectiveness in their own circumstances. Cultural differences can appear to present insuperable barriers. The anticolonial movement in India inspired many African Americans, but there was considerable debate about the applicability of Gandhian tactics (Chabot 2000). W. E. B. Du Bois (1943) claimed that fasting "would be regarded as a joke or as a bit of insanity" in England or America. ${ }^{4}$

Needless to say, the adoption of a tactic also depends on the various determinants of protest in general-grievances, opportunities, resources, networks, identity, and so on. But knowing about a novel tactic could lead people to protest where they would not otherwise have done so, if the tactic seems more feasible, more legitimate, or more effective than their existing tactics. Analyzing the civil rights movement, McAdam (1983) shows that upsurges of protest coincided with the adoption of new tactics: the bus boycott, the sit-in, and the freedom ride.

If people adopt a novel tactic and find it effective - relative to other tactics they have practiced - then they are likely to repeat it on subsequent occasions. Over time, however, a tactic may lose efficacy. For one thing, opponents and authorities may develop countermeasures (McAdam 1983). Egyptian demonstrators in 2011 improvised techniques of fraternization when confronted by armored units; by swarming over vehicles, kissing troops, and chanting their appreciation for the army (counterposed to the hated police), protesters arguably made repression impossible (Ketchley 2014 in press). These techniques required proximity, however, so the army subsequently deployed hardened military police to keep protesters at a safe distance. In addition, any tactic that depends on media coverage almost inevitably loses effectiveness with iteration, as it becomes less newsworthy. Over the longer term, a tactic can be undermined by exogenous change. Advances in military technology and reconfigurations of urban space eroded the barricade's practical efficacy after 1830, though it remained potent as a revolutionary symbol (Traugott 2010).

Even if a tactic remains feasible, legitimate, and effective, it will not survive without being used. A tactic remains in the repertoire through repetition and adoption. There are natural limits to repetition since memories fade and people die. A tactic is unlikely to be revived after lying dormant for many decades, at least in modern societies where protest tactics are not transmitted between generations as traditions. ${ }^{5}$ An implication is that modular tactics - those "easily transferable from one circumstance to another instead of being shaped tightly to particular uses" (Tilly 1995: 45) - will tend to survive. As a movement or campaign fades, whether in success or failure, the tactics that are peculiar to it will no longer be repeated. The shantytowns built by American students during the campaign against South African Apartheid in the 1980s provide an example (Soule 1999). To avoid tautology, it is crucial to ascertain the potential for modularity by focusing on the tactic itself. Shantytowns symbolized the poverty of people in underdeveloped countries; the tactic could be adopted for a campaign to cancel Third World debt, but it would make no sense for most social movements. Note that a potentially modular tactic may or may not be adopted for varying causes in diverse circumstances. Compare the demonstration and the hunger strike. The former is used by every social movement; the latter is not.

My theoretical reformulation-distinguishing invention, adoption, and repetitionfocuses attention on the evolution of repertoires. The proposition that repetition is far more likely than adoption will not be considered further here. Suicide protest, of course, is not repeated. ${ }^{6}$ Every instantiation of this protest action was either invention or adoption, which 
facilitates testing the proposition that individuals are far more likely to adopt a known tactic than to invent it anew. By implication, instances of a tactic can be arrayed into one or more lineages: each lineage originates with an invention, which then inspires a succession of adoptions, radiating across social and geographical space. Note that multiple independent inventions are possible. Note also that an invention need not inspire adoption. "Most innovations fail and disappear," as Tilly (1995: 44) observes. Nevertheless, only if most instantiations of a tactic belong to one or a few lineages does the concept of a repertoire have explanatory force.

\section{SUICIDE PROTEST}

As a discrete individual action, suicide protest manifests less variability than tactics such as the strike or the demonstration. The definition should be sharpened, though, to differentiate it from other types of what Durkheim (1897) terms "altruistic suicide." This paper restricts suicide to actively killing (or attempting to kill) oneself, as distinct from voluntarily seeking martyrdom (e.g., Stark 1996: ch. 8). Protest combines two types of illocutionary acts, expressive and directive: "an expression of disapproval and a petition for change" (Searle 1976: 22). This serves to distinguish suicide as protest from suicide to avoid capture or execution (e.g., Geertz 1980: 11, 141-2), to express atonement, to follow a master or husband into death (Fisch 2005), or to achieve a more exalted state.

Thus defined, suicide protest is not often recorded before the twentieth century. Two sociologists—Durkheim (1897: esp. part II, ch. 4) and Westermarck (1908) — published compilations of ethnographic and historical evidence on suicide. In their pages, only one instance meets my definition (Westermarck 1908: 20; from Chevers 1870: 659-60; from Tod 1832: 401-02). In Rajasthan in the mid eighteenth century, wealthy Brahmins protested when a lord levied exceptional taxes to fund his army. Some stabbed themselves to death in his presence while cursing him. As a result, the lord was ostracized; the raja of Jaipur, implicated in the guilt of his vassal, made amends by giving money to Brahmins in his capital. Durkheim and Westermarck could have noticed more recent examples of suicide protest. In Tokyo in 1891, a militia lieutenant named Ohara Takeyoshi committed seppuku — ritualized disembowelmentto warn of the Russian threat and to urge higher spending on the armed forces (Hearn 1894: 391; Chamberlain 1905: 219-20).

The dimensions of suicide protest before the twentieth century are beyond reach, if only because motivations are opaque in surviving sources. One feature is worth noting. Many premodern instances depended on supernatural intermediation. By killing yourself, you will harm your adversary either because you are transmuted into a ghost or-more abstractlybecause the cosmic order will exact retribution. This is an odd kind of social mechanism: it is entirely fictitious from a sociologist's standpoint, and yet it is potent as long as people believe in it. This mechanism was operative in the case of the Brahmins in Rajasthan, and similar examples are found in South India in the eighteenth century (Hill 1914: 59; India 1953: 28586; Krishnan 1983: 94).

In the twentieth century, however, supernatural intermediation virtually disappeared. ${ }^{7}$ Instead, suicide protest was intended to persuade human audiences: by appealing to distant third parties or by exhorting the collectivity to greater effort. Korea provides an important transitional example. In 1905, the Emperor was forced to sign a treaty recognizing his country as a protectorate of Japan. Min Yonghwan, an official from the governing elite, then cut his throat with a dagger (Finch 2002). Drawing on the Confucian model of a loyal official taking his life after the ruler spurns advice, his final statements followed the form of an apology. But their content was novel, making protest explicit. He addressed messages to the representatives of the major powers, urging them to protect Korea from Japanese predation. Another message was addressed to "twenty million fellow citizens," calling on them "to make one million times more effort" to "restore our freedom and independence" (Finch 2002: 175). ${ }^{8}$ The consequence 
of Min's sacrifice showed the potential of suicide protest. His death was belatedly reported in the New York Times (December 4, 1905, p. 4) and The Times of London (December 5, p. 5), though this did not perturb American and British acquiescence to Japanese imperialism. But his action had great effect within Korea. The emperor praised his patriotism, and gave him all the honors of an official funeral, which provided an occasion for ordinary people to express their hostility to Japan.

By the twentieth century, structural transformations were enhancing the feasibility and effectiveness of suicide protest. The development of news media enabled an event to be quickly communicated to a vast audience. As Koopmans (2004: 368) argues, for modern protest "it is no longer the co-present public that counts most, but the mass audience that sits at home and watches or reads the media coverage." Ohara in 1891 was a forerunner, for his statement stipulated that it should be passed to the Tokyo News Agency (Chamberlain 1905: 219-20). ${ }^{9}$ The impact of Min's sacrifice also owed much to news media: his message was publicized by a newspaper owned by an English missionary, whose nationality protected him from censorship by the Japanese rulers of Korea (Chong 1987).

Another transformation was the end of cruel public punishment inflicted by the state. Premodern executions were organized as a public spectacle and designed to inflict pain on the person and degradation on the corpse (Elias 1939: part II, ch. 10; Foucault 1975; Tocqueville 1840: part III, ch. 1). The abolition of such executions in Western Europe and the United States in the nineteenth century is well known (e.g., Gatrell 1994). Less has been written about this shift in other cultures, but modernizing states typically adopted Western practices in punishment (Rejali 1994). ${ }^{10}$ In Japan, for instance, seppuku had long been used as a criminal penalty; the condemned man was commanded - or perhaps permitted, because it was an honorable practice - to kill himself in this manner. Following the Meiji restoration, that penalty was abolished in 1874 (Fusé 1980: 59). The transformation of punishment does not imply that modern states are benign; they simply prefer incarceration to execution, and prefer to conceal rather than flaunt their violence (perfected in the "disappearance"). This aspect of the modern state has escaped the attention of scholars of contentious politics, but it is surely relevant for the repertoire of protest. It makes tactics based on self-inflicted suffering-such as hunger strikes and suicide protest-more feasible, in the sense that it would not be necessary for protesters to harm themselves if the state would publicly and avowedly inflict cruel punishment on them.

These long-running transformations, already well underway by the twentieth century, gradually reshaped the environment for protest tactics. Although instances of suicide protest can be identified throughout history, only in Japan did the tactic have a lineage continuing from the nineteenth century (explored further below). ${ }^{11}$

\section{METHOD}

To investigate suicide protest over many years and multiple countries, it is necessary to systematically search newspapers (Earl et al. 2004; Franzosi 1987; Maney and Oliver 2001; Olzak 1989). Needless to say, any newspaper reports only a fraction of protest events (McCarthy, McPhail, and Smith 1996; Oliver and Maney 2000; Oliver and Myers 1999; Ortiz et al. 2005). Suicide protest is exceptional on two counts. First, it is the limiting case of violence, and violent events are more likely to be reported (e.g., Barranco and Wisler 1999; Myers and Caniglia 2004). Second, the act is extremely rare, so the saturation effectwhereby events become less newsworthy with repetition - can be discounted (Myers and Caniglia 2004). Sociologists have generally used newspapers to identify local or national events. International coverage is more problematic (Mueller 1997; Woolley 2000), but the New York Times and The Times of London are used for compiling crossnational data on laborcapital conflict (Silver 2003) and newswires for ethnic conflict (Olzak 2006). Suicide protest is less common and more spectacular than either. 
I have gathered systematic data for the period from 1919 to 1970 . This period is chosen to provide several decades before the pivotal year of 1963 . The primary sources used are the New York Times and The Times because they have been digitized, enabling the text to be searched for keywords. ${ }^{12}$ I utilize four sets of search terms: "immolation" and its derivatives; "protest" and "suicide" in combination; phrases including "killing oneself" or "oneself to death," and their cognates; phrases including "suicide by fire," and "oneself on fire" and their cognates. ${ }^{13}$ A report is included in the dataset if it provides some specific information (at least two of name, date, and location within country). Attempts at suicide that did not result in death are included ( 5 percent of individuals are known to have survived, and a further 8 percent are likely to have survived), but threats are excluded. Deaths in prison are omitted because it is often impossible to distinguish protest suicide from ordinary suicide, death from natural causes, or murder by the authorities. Theoretically, this exclusion has some justification because a prisoner - if facing many years of incarceration - has less to live for.

Systematic search of newspapers yields 114 acts of suicide protest; a further 19 come from other sources. ${ }^{14}$ Table 1 shows the distribution by source, and table 2 by country. The New York Times reported three quarters of the acts, whereas The Times reported half of them. This difference is not due to the United States' involvement in South Vietnam, since the New York Times also reported more acts in India. Given my sources, it is reassuring that only 12 percent of the acts occurred in anglophone countries. To counteract the bias towards domestic news, one could (following Silver 2003) count only those acts in the United States reported by The Times and only acts in the United Kingdom reported by the New York Times. This alternative accounting would halve the number of cases in each country, so that the United States would contribute 6 percent of the revised total.

Although it is impossible to estimate the number of acts omitted, two sources of ignorance should be acknowledged. First, a newspaper has limited space. When a report of suicide protest comes over the newswire, an editor might decide not to run the story because space has been filled by reports judged more important. While individual acts could be crowded out, it seems likely that waves of suicide protest-in which several individuals sacrifice their lives for the same cause within a span of days or weeks-would generally warrant newspaper space, as long as these cases were known. This leads to the second source of ignorance, which is a greater concern. Totalitarian states, like the Soviet Union and Maoist China, had the power to prevent information from reaching the outside world. The fall of communism in Eastern Europe and the easing of restrictions in China, however, have mitigated this problem. New information emerges on cases that newspapers did not report at the time, like that of Ryszard Siwiec in Poland in 1968 (NYT, April 26, 1992, p. H26). ${ }^{15}$ New evidence may also confirm the absence of suicide protest, on a large scale at least, as seems to be the case during the Chinese Cultural Revolution (Lester 2005; Phillips, Liu, and Zhang 1999).

Figure 1 depicts the distribution of suicide protest by country and year. Before 1963, there were 32 suicide protests in 44 years. The time series then increases dramatically. In June 1963, Thich Quang Duc set himself on fire in Saigon. His act was followed by ten others before the year's end. From 1963 to 1970, there were 101 suicide protests. Compared to the

Table 1. Suicide Protest by Source, 1919-1970

\begin{tabular}{lccccc}
\hline Country & NYT only & NYT and Times & Times only & Other sources & Total \\
\hline United States & 7 & 5 & 2 & 0 & 14 \\
United Kingdom & 0 & 1 & 1 & 0 & 2 \\
Other countries & 44 & 44 & 10 & 19 & 117 \\
Total & 51 & 50 & 13 & 19 & 133 \\
Percent & $38 \%$ & $38 \%$ & $10 \%$ & $14 \%$ & $100 \%$ \\
\hline \hline
\end{tabular}


Table 2. Suicide Protest by Country, 1919-1970

\begin{tabular}{lccc}
\hline \hline Country & Number & Percent & Years \\
\hline South Vietnam & 52 & $39.1 \%$ & $1963-1970$ \\
Japan & 17 & $12.8 \%$ & $1924-1970$ \\
United States & 14 & $10.5 \%$ & $1931-1970$ \\
India & 10 & $7.5 \%$ & $1964-1965$ \\
South Korea & 7 & $5.3 \%$ & $1960-1970$ \\
China & 6 & $4.5 \%$ & $1919-1948$ \\
Czechoslovakia & 4 & $3.0 \%$ & $1969-1970$ \\
Soviet Union & 3 & $2.3 \%$ & $1966-1969$ \\
France & 3 & $2.3 \%$ & $1969-1970$ \\
United Kingdom & 2 & $1.5 \%$ & $1969-1970$ \\
Spain & 2 & $1.5 \%$ & $1969-1970$ \\
Malaysia & 2 & $1.5 \%$ & 1967 \\
Hungary & 2 & $1.5 \%$ & $1938-1969$ \\
Yugoslavia & 1 & $0.8 \%$ & 1933 \\
Switzerland & 1 & $0.8 \%$ & 1936 \\
Sri Lanka & 1 & $0.8 \%$ & 1963 \\
Romania & 1 & $0.8 \%$ & 1970 \\
Poland & 1 & $0.8 \%$ & 1968 \\
Philippines & 1 & $0.8 \%$ & 1930 \\
Italy & 1 & $0.8 \%$ & 1970 \\
Germany & 1 & $0.8 \%$ & 1933 \\
Brazil & $133 \% 54$ \\
\hline Total & $100.0 \%$ & \\
\hline \hline
\end{tabular}

Figure 1. Suicide Protest, 1919-1970

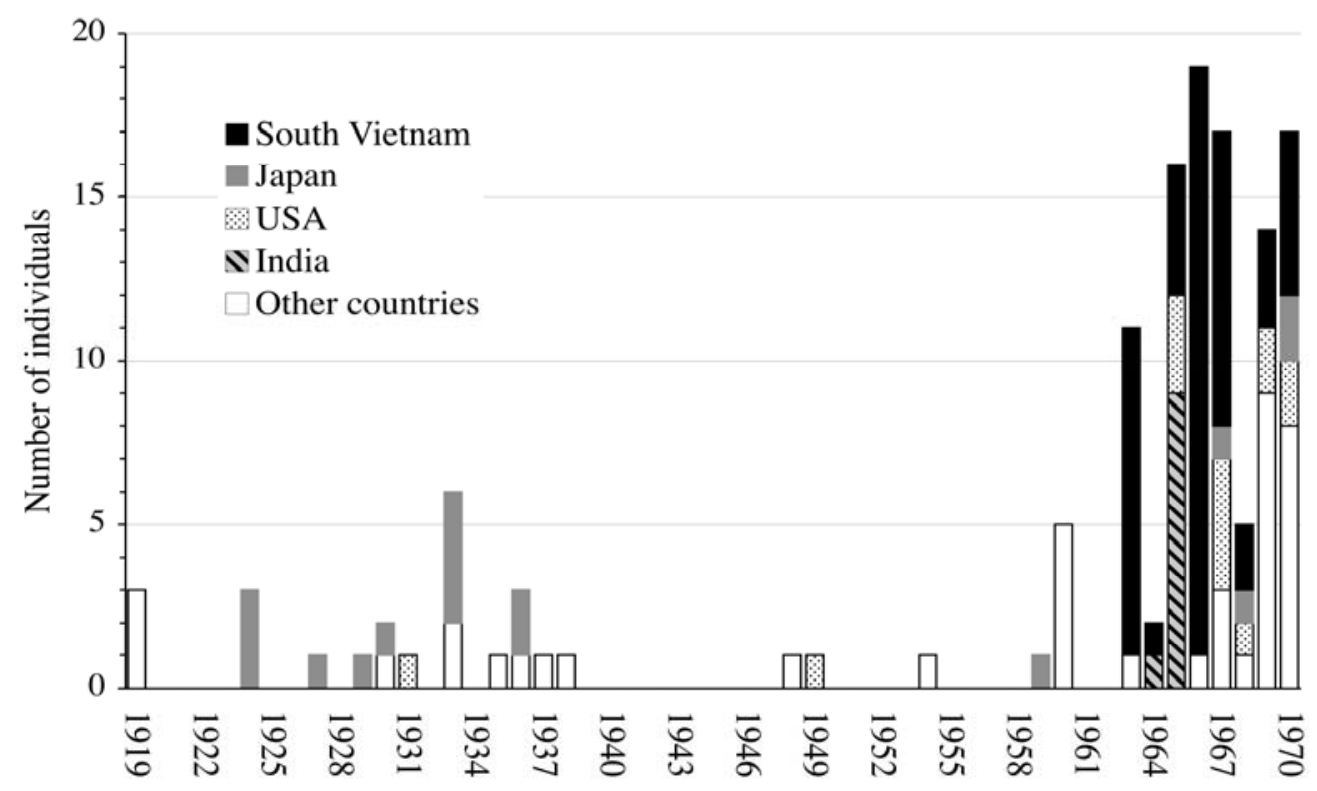


period 1919-62, the annual rate (per urban population) increased nine-fold. ${ }^{16}$ Although South Vietnam contributed half of all suicide protests in the later period, it does not account for all the increase; excluding that country, the annual rate quadrupled. This surge cannot be attributed to any increasing trend in the coverage of international news. Indeed, the rate of suicide protest was higher in the 1920s and 1930s than in the 1950s. The break in the time series in 1963 is the first piece of evidence that Quang Duc's immolation was crucial.

\section{INVENTION TO 1963}

Some acts of suicide protest were idiosyncratic. Hal Huston shot himself at a picnic ground in Pennsylvania in 1931, denouncing the government for "wanton destruction of national resources" and being "too inefficient in management to maintain respect" (NYT, October 2, p. 4). Especially poignant is the example of Stefan Lux, who shot himself at the League of Nations in 1936 (Hahn 1936). He carried letters to the League's secretary general, the government of the United Kingdom, and two British newspapers. "My purpose is no other than to secure that public opinion in England, which in consequence of insufficient knowledge of the true facts shows at times regrettable inclinations towards Hitlerist Germany" (Manchester Guardian, July 7, p. 15). For Lux and Huston, as for most other cases before 1963, there is no indication that they had adopted the tactic from elsewhere; it appears as an independent invention. Likewise, their acts were not adopted by others.

In Japan, by contrast, at least thirteen cases continued the lineage from the late nineteenth century. Because suicide protest was a self-conscious reincarnation of the samurai tradition, the signature method (though not used in every case) was seppuku. This lineage was bound up with militaristic and nationalistic causes. In 1924, for example, a man identifying himself as a "Nameless Subject of the Japanese Empire" committed seppuku to protest against American legislation that excluded immigrants from Japan (NYT, June 1, p. 1; June 2, p. 4; June 3, pp. 1, 7, June 4, p. 4; Times, June 4, p. 17). Nationalist societies organized a huge funeral, and his remains were eventually interred alongside other national heroes in the military cemetery (NYT, November 12, p. 22). Two others soon followed his example (Hirobe 2001: 33; Makela 1972: 163-67). The sole exception to the association with nationalism is a Buddhist monk, Shuntetsu Kobayashi, who killed himself in 1959 to protest against Japanese rearmament; the exception is only partial, because he also denounced the American occupation of Okinawa (NYT, June 5, p. 7; Japan Times, June 4, p. 3).

There is no indication that the Japanese lineage inspired the adoption of suicide protest in other countries. Only in one case was there any resemblance to seppuku. In 1960, five monks in Seoul wounded their stomachs with knives (though not fatally) after a legal dispute between different Buddhist factions (Korean Republic, November 25, p. 2). That the Japanese lineage did not inspire adoption elsewhere is readily explained. It drew legitimacy from the samurai tradition which was peculiar to Japan, and was associated with a bellicose nationalism that was repugnant to the rest of the world. This nationalism had been discredited even in Japan by defeat in 1945. From the vantage point of the middle of the twentieth century, suicide protest would have appeared an atavistic relic, destined to fade into obscurity.

All this changed with the immolation of Quang Duc in 1963. It arose out of Buddhist resistance to religious discrimination practiced by the government of President Diem, a devout Catholic. On Buddha's Birthday in 1963, there was a demonstration against the banning of Buddhist flags in Hué. It was attacked and several protesters, including children, were killed (Oka 1966: 5-6; Jones 2003: 246-51; Wulff 1963). Monks held demonstrations and went on hunger strike in many cities. Then Quang Duc asked permission to burn himself as a donation to the "three jewels"-Buddha, teaching (Buddhadharma), and community (Giac Duc 1986: 142). 
He was drawing on an ancient tradition within Mahayana Buddhism, which predominated in Vietnam. Chinese Buddhist texts from the fourth century onwards describe monks choosing death, usually by fire (Benn 2007). The practice continued into the twentieth century (Welch 1967: 508). We could classify these suicides as intended to achieve a more exalted existence after death, though this would oversimplify: death was believed to influence the cosmic order. In the early twentieth century, a Chinese monk self-immolated "to cause the Buddhadharma to flourish, and to turn people's minds around...to cause all tendencies for killing between heaven and earth to cease" (Benn 2007: 170-71). A few of the ancient suicides could have been protesting against threats to Buddhism from the Chinese state, though the hagiographic texts are difficult to decipher. Certainly Quang Duc would have known this textual tradition. Entering the monastery as a young boy early in the twentieth century, he would also have known of monastic suicides by fire in French Indochina in the 1920s and 1930s (Brodrick 1942: 88; Le Monde, Aug. 24, 1963, p. 2; Aug. 25, 1966, p. 3). Although the tradition of selfburning in Mahayana Buddhism lent legitimacy to Quang Duc's action, this was not uncontroversial. Some texts argued that self-burning counted as suicide and was therefore proscribed. Younger monks initially dismissed his request to burn himself as "exotic and horrible" (Giac Duc 1986: 141).

Quang Duc's action was deliberately staged as a spectacle for the news media. In this respect, the action had a second author: Thich Duc Nghiep, one of the activists leading the campaign against the government. Fluent in English, he had close relations with foreign journalists (Browne 1965: 175, 177). He was the first to endorse Quang Duc's request; he clearly understood the potential international impact (Giac Duc 1986: 140, 142). When the immolation was approved, it was thoroughly planned. A detachment of monks and nuns prevented fire engines from reaching the scene by lying under their wheels. Most importantly, journalists were alerted beforehand. Thus Malcolm Browne, working for the Associated Press, captured the scene on camera. A monk with loudspeaker intoned, "A Buddhist priest burns himself for five requests," while others distributed the text of Quang Duc's final message - all in English. "Before closing my eyes to go to Buddha, I have the honour to present my words to President Diem, asking him to be kind and tolerant towards his people and enforce a policy of religious equality" (Joiner 1964: 918). He also exhorted others "to organise in solidarity to make sacrifices to protect Buddhism."

Quang Duc's action responded to the opportunity created by the media, but also to the decline of public cruelty by the state. This may seem farfetched as the Diem regime was certainly authoritarian and the precipitating incident was the massacre at Hué. But the massacre was probably the result of overreaction by local troops rather than a deliberate order from the capital. Most importantly, the government blamed the deaths on a grenade attack by the Viet Cong. This disavowal was plausible, so there was no embarrassment to American foreign policy. Consider a historical comparison. In 1835, after putting down a rebellion with mass slaughter, the Vietnamese king transported the leaders to his capital, Hué, and had them publicly tortured to death (Chapuis 1995: 192-193). If the Diem regime had done this with the leaders of the Buddhist movement, suicide protest would have been redundant.

\section{ADOPTION FROM 1963}

Quang Duc's death was followed by an unprecedented number of suicide protests, as seen in figure 1. South Vietnam will be considered first. There is no doubt that suicide protest was adopted from Quang Duc's original act. A celebrated poet, Nguyen Tuong Tam, took poison in July 1963. The model was explicit: "like the high priest Thich Quang Duc, I also kill myself as a warning to those people who are trampling on all freedoms" (NYT, July 9, p. 4). Subsequent acts of suicide protest revealed their model implicitly, by using the method of fire. Out of a total of 52 in South Vietnam, only three (Tam and two others) used another method. 
The tactic's adoption can be explained in terms of knowledge, legitimacy, and effectiveness. The fact that Quang Duc's death occurred in the middle of Saigon meant that information could not be suppressed. The circulation of American newspapers and magazines hindered censorship (just like the missionary newspaper in Korea that publicized Min's death in 1905). The photograph of Quang Duc, "touched up to show the skeleton through the fire" (Hope 1967: 151), was quickly displayed in pagodas across the country. This highlights the act's legitimacy for Buddhists. Buddhist leaders endorsed suicide protest, insisting that it was not the kind of suicide forbidden by religious teaching. Indeed, the act inspired reverence. A student who witnessed Quang Duc's death recalled that "a deep vow sprang forth from me: I too would do something for the respect of human rights in as beautiful and gentle way" (Chân Không 1993: 38). The effectiveness of Quang Duc's act was immediately visible. After his death, many lay people joined the monks and nuns who were protesting on the streets of Saigon. The impact was apparent even to the regime, despite its insensitivity to public opinion. Diem hurriedly negotiated with Buddhist leaders to avoid a public funeral. In the event, thousands of women rioted as police tried to prevent them from attending.

A large number of Vietnamese knew of Quang Duc's immolation, considered it legitimate, and saw that it was effective. Not surprisingly, then, the tactic was adopted by others. Within five months, Tam took poison and seven others set themselves alight. The regime tried various countermeasures. It suggested that monks had been drugged and murdered or had committed suicide over love affairs, but these claims were evidently absurd (NYT, August 6 , p. 3). It confiscated the body of a monk in order to prevent his funeral becoming the occasion for protest, but this merely provoked another immolation (Times, August 16, p. 7).

Suicide protest not only catalyzed mobilization within South Vietnam, but also had a huge impact on the United States. The sacrifice of one elderly monk altered the calculations of a superpower. As the National Security Council telegraphed, "one more burning bonze will cause domestic U.S. reaction which will require strong public statement despite danger that this might precipitate coup in Saigon" (Glennon, Keefer, and Smith 1991: 432). The photograph of Quang Duc was on President Kennedy's desk when he briefed the new ambassador, assigned to force Diem to compromise with the Buddhists (Browne 1993: 12). In defiance of the United States, the regime pursued repression rather than concession, launching a concerted attack on the pagodas in August. This was Diem's fatal mistake (cf., Kahin 1987: 431). In defending the decision in Washington, D.C. to support a coup in November, the secretary of state explained: "We cannot stand any more burnings" (Jones 2003: 317). At the time, of course, information about the machinations of American foreign policy was not publicly available. Nevertheless, the fact that the regime was overthrown five months after the first suicide protest surely reinforced belief in the tactic's effectiveness.

Suicide protest was now established in the South Vietnamese repertoire. It was adopted in campaigns against subsequent regimes, notably in 1966 when 14 burned themselves to death in the course of a month. These suicide protests failed to inflict the same damage on the government, in part because the Buddhist movement had come to oppose the war as well as the regime - and was therefore viewed by the United States as a hostile force to be repressed rather than conciliated (Topmiller 2002). The fact that the movement was not able to achieve its ultimate goals, as it had in 1963, did not diminish the adoption of suicide protest within South Vietnam.

This lineage could have been confined to South Vietnam, thus resembling the Japanese lineage. Remarkably, Quang Duc's sacrifice-and those of subsequent Buddhists in Vietnam - inspired adoption in other countries. (These acts in turn inspired further adoption, as will be discussed below.) Aside from the quantitative increase in suicide protest seen in figure 1, two other kinds of evidence allow us to trace the reverberations of his action.

One is the testimony of the individuals themselves. Within a month of Quang Duc's death, 2,000 miles away in Sri Lanka, Vidanage Vinitha leapt to her death from the headquarters of the health ministry. Nurse aides were on hunger strike because they refused to clean the wards 
Table 3. Suicide protest by method, 1919-1970

\begin{tabular}{lccc}
\hline \hline & $\mathbf{1 9 1 9 - 1 9 6 2}$ & $\mathbf{1 9 6 3 - 1 9 7 0}$ & $\begin{array}{c}\text { 1963-1970 Excluding } \\
\text { South Vietnam }\end{array}$ \\
\hline Annual average by fire & 0.02 & 11.3 & 5.1 \\
Annual average by other method & 0.5 & 1.4 & 1.0 \\
Fire as percent of total & $4 \%$ & $89 \%$ & $84 \%$ \\
\hline \hline
\end{tabular}

"Thousands weep over the fate of a Buddhist monk in South Vietnam," she wrote, "but nobody cares about 400 Sinhalese girls in our own land" (Times, July 16, p. 8). In the United States in 1965, Alice Herz set herself on fire to protest against the government's militarism. "I have chosen the flaming death of the Buddhists," she explained (Shibata 1976: 4, also 18).

Such explicit evidence is rare; individuals did not usually mention their model. The method of killing provides a second kind of evidence. In the decades before 1963, people who killed themselves as an act of protest generally used a gun or a knife; there are also single instances of hanging, taking poison, leaping from a building, and jumping under a train. Burning occurred in only one case: a Buddhist monk in China set himself on fire in 1948, apparently to protest against Communist persecution (Ci Xing Temple 1958: 26; Welch 1967: 327). The story emerged in Hong Kong years later; how his intention was known is unclear because the act is described as solitary and no written testament is mentioned. As we have seen, other Buddhist monks had burned themselves to death in the twentieth century, but these were not acts of protest. When Buddhist monks in Japan and South Korea (in 1959 and 1960 respectively) chose to harm themselves for a collective cause, they used knives. From 1963 onwards, however, the vast majority of suicide protests were by fire, as shown in table $3 .{ }^{17}$ The dominance of fire holds equally when South Vietnam is excluded.

Even in countries with local precedents for suicide protest, burning became the preferred method. In Japan, a laborer killed himself in 1967 to protest against the government's proAmerican stance on Okinawa and the war in Vietnam. He did not use seppuku-like Kobayashi less than a decade earlier - but set himself on fire. In South Korea, a politician killed himself in 1965 to protest against a treaty normalizing relations with Japan. His act echoed Min's protest against annexation by Japan, but he eschewed Min's method and chose burning instead. The method hardly resonated with the cause, for cremation had been imposed under Japanese rule in the 1930s (Park 2005: 290-91). The same shift occurred in two Indian movements for regional autonomy. A Tamil laborer set himself on fire to protest against the imposition of Hindi in 1964. He chose not to follow the example of a famous activist who starved to death less than a decade before in southern India, demanding that the government carve out a new state for Telugu speakers (Sreeramulu 1988). At the other end of the subcontinent, a Sikh leader threatened to burn himself to death in 1965 unless the government created a new Punjabi state (Grewal 1990: ch. 9). ${ }^{18}$ This was a change from just a few years before, when Sikh leaders had threatened to fast until death.

Not every case of suicide protest after 1963 was part of the lineage originating in Saigon. The clearest example comes from Japan. The novelist Yukio Mishima staged an elaborate double suicide on behalf of right-wing nationalism in 1970 (Nathan 1974; Scott-Stokes 1975). After the group of five kidnapped a general, Mishima and one of his followers committed seppuku and were then beheaded. He had celebrated this tradition in writing and film; one of his famous stories was inspired by the suicide of Aoshima Kenkichi in 1936 (Mishima 1961). Ironically Aoshima's protest had been directed against soldiers who were attempting an ultranationalist coup (NYT, March 2, 1936, p. 1; Shillony 1973: 191-92).$^{19}$ Mishima and his confederate were exceptional. Almost all acts of suicide protest from 1963 onwards can be traced - directly or indirectly - back to Quang Duc's sacrifice. The great majority of individuals adopted the method of burning along with the tactic. 
Why, then, did people in other countries adopt suicide protest from South Vietnam? Again, this can be explained in terms of knowledge, effectiveness, and legitimacy. Quang Duc's sacrifice garnered greater publicity than any previous instance. Saigon was on the frontline of the Cold War-hence the presence of so many Western journalists. On the other side of the iron curtain, communist regimes exploited Quang Duc's death as anti-American propaganda. The cause also attracted the attention of Buddhists in countries like Sri Lanka and Thailand; they spurred the United Nations to dispatch a mission to South Vietnam. A vital element in this publicity was the photograph of his fiery death, reproduced in countless newspapers - though the New York Times initially considered it too graphic to print-and magazines (e.g., Life, June 21, 1963, p. 24). It won the World Press Photograph Award for 1963. China distributed the image throughout Asia and Africa (Browne 1965: 182). Certainly this visual image distinguishes Quang Duc's death from any previous instance of suicide protest. Knowledge has degrees of salience. An image raises salience, especially when it provokes strong emotion (Braun and Koopmans 2010; Jasper and Poulsen 1995).

How important was Quang Duc's particular method of self-killing? Fire made it possible for the act of death to be photographed and reproduced. An image of seppuku, by contrast, would be too gruesome for publication, at least in Western media. ${ }^{20}$ Like seppuku, fire is a method of self-killing that overtly maximizes pain. It enhances the exhortation and the appeal by demonstrating willingness not just to die for the cause, but to die in agony. At the same time, however, fire could be considered more feasible than seppuku in the sense that it requires only a single instant of self-mastery, the moment of ignition. This suggestion may seem perverse, but it is consonant with the adoption of the method of burning for other kinds of suicide. In Western countries, burning was almost unknown before 1963; after Quang Duc's immolation, it was adopted by a significant minority of people committing suicide for personal reasons (Bourgeois 1969; Crosby, Rhee, and Holland 1977).

Once known, a tactic has to be evaluated for its effectiveness. When someone in France or India or Japan saw the image of the burning monk, they instantly knew that suicide protest could attract the attention of distant audiences. The same logic holds for a few earlier acts that were widely reported, but the image of Quang Duc accentuated the effect. A more substantive criterion for assessing the efficacy of suicide protest is the response of the collectivity for whom the act was undertaken. It was soon clear that Quang Duc's act had an extraordinary impact in South Vietnam. The only comparable reaction reported in the New York Times or The Times (from 1919 onwards) was for the "Subject of the Japanese Empire" in 1924.

The efficacy of suicide protest in South Vietnam was apparent by the end of 1963. Adoption of the tactic in a different social context is most easily explained when it was used for a related political cause. For opponents of American foreign policy, the tactic's symbolic association was crucial. This association accounts for many cases in the United States. Most notable was Norman Morrison who set fire to himself outside the Pentagon in 1965. His action gained attention but little sympathy within the United States. Even his fellow Quakers prayed that people would "see beyond the act" (NYT, November 4, p. 5). Americans could consider suicide protest legitimate for Buddhists in Vietnam, but not for Christians at home. ${ }^{21}$

If suicide protest had remained associated with American policy in Southeast Asia, then the tactic would not have endured. Its potential modularity was soon realized. Indeed, the very first adoption of Quang Duc's act (by Vinitha in Sri Lanka) occurred in a completely unrelated conflict. In some countries, suicide protest gained legitimacy from cultural traditions. An example is India, where there were longstanding Hindu traditions of self-sacrifice. Isolated cases of sati - the voluntary burning of a widow on her husband's funeral pyrecontinued into the twentieth century (Fisch 2005); a Hindu ascetic set himself on fire in 1937 (Times, July 21, p. 14). The tradition of cremation gave death by fire the association of sanctity rather than horror.

At the furthest social distance from its origin was suicide protest against Soviet hegemony in Eastern Europe. There were no comparable legitimating traditions and no affinity 
with the issue of Vietnam. In 1968, Siwiec set himself on fire during a state festival, shouting "Long live free Poland!" and other slogans (Drygas 1991; Eisler 2010: 215-18). ${ }^{22}$ Information was suppressed by the authorities. Four months later came the immolation of Jan Palach in Czechoslovakia. His message addressed fellow citizens, exhorting them to do more to resist the Soviet occupation. He even pretended that he was the first of a group ready to sacrifice themselves: "If our demands are not fulfilled within five days...more torches will burn" (Treptow 1989: 40). Palach's death had tremendous impact in Czechoslovakia. His funeral was massive, with hundreds of thousands of mourners turning out to honor his memory and to rebuke the pro-Soviet regime. Even the President was forced to publicly acknowledge his "noble nature and honest aspiration" (Treptow 1989: 41). His grave remained a site of pilgrimage for years afterwards, attracting so many visitors that the regime eventually removed it from the capital. The response of Czechoslovaks to Palach's death differed markedly from the response of Americans to Morrison's. In both countries, suicide protest was an alien import. However, one crucial difference is that American citizens had many opportunities to make their voices heard, through institutional politics and conventional protest, and therefore such an extreme act seemed unnecessary. In addition, only a minority of Americans felt such passionate opposition to the Vietnam War at that date, whereas the vast majority of Czechoslovaks opposed Soviet occupation. ${ }^{23}$

By the end of the 1960s, the lineage of suicide protest had branched into many different countries. Models outside South Vietnam were now mentioned. A teacher who set fire to herself in Saigon mentioned Morrison as well as Quang Duc (Hassler 1970: 201). Palach inspired suicide protest in his own country and also in Hungary, the Soviet Union, and England (Bauer 1969: 407; Rips 2010: 171-2; Times, March 18, 1970, p. 2). ${ }^{24}$ A Basque separatist, Joseba Elosegi, wrote in his diary in 1970:

I have always admired the actions of those Buddhist bonzes who, in order to protest injustice committed against the people, publicly set their own bodies on fire. Like the case of that young Czechoslovakian communist who revolted against the Soviet occupation of his country. Wouldn't I be able to do the same?" (Elosegi 1971: 24)

A month later he draped himself in a Basque flag and set himself alight in front of General Franco.

Adoption of suicide protest across countries did not involve personal networks; it was "nonrelational" diffusion, with information conveyed by news media (Tarrow 2010). Morrison is an example. He had no personal relationships with Vietnamese Buddhists, but he knew of their suicide protests. He was also acutely aware of the suffering of people in South Vietnam, once again through news reports; the impulse to act came after reading about an American air raid. He had no personal connection with Herz, but he knew about her act from a newspaper (Morrison Welsh 2003: 153-154). The impact of his death was likewise mediated through news reports. His wife received letters from all over the world. "Our little country stands in awe before the heroic self-sacrifice of your husband," wrote someone from Hungary (Steinbach 1995: 4K). None of these connections depended on personal relationships.

Note finally that the adoption of suicide protest was an unintended consequence. Individuals committing suicide protest did not wish to encourage emulation. Palach explicitly warned against it. "My act has achieved its purpose," he announced from hospital as he lay dying, "but it would be better if nobody else repeats it" (Treptow 1989: 40). Despite his plea, at least six others adopted suicide protest over the next four months.

\section{CONCLUSION}

This article has investigated one particular tactic in the repertoire of contention. There were instances of suicide protest before the twentieth century, which generally depended on super- 
natural intermediation. In modern societies, the tactic has achieved its effect by exhorting others to contribute to the collective cause and by appealing to distant audiences. The shift in state repression away from public cruelty created a space for self-inflicted suffering; to put it crudely, when protesters are no longer publicly martyred, then martyrs must be self-made. The growth of news media enabled spectacular self-inflicted suffering to reach a global audience. Responding to these long-term transformations, people invented the tactic of suicide protest several times. The inventions drew on diverse cultural traditions - samurai, Confucian, Buddhist — or, in some cases, no apparent tradition at all. Before 1963, a lineage of suicide protest existed only in Japan.

The extraordinary effect of Quang Duc's immolation can be attributed to a number of factors. He died by fire. His death was orchestrated to maximize publicity and was captured on camera. Saigon had global significance, due to the Cold War. The regime relied on the U.S. government, which was sensitive to American (and global) public opinion, so suicide protest could embarrass the imperial power. Reliance on the United States also hindered the regime's attempts to suppress information. These contingencies are crucial for explaining how suicide protest entered the global repertoire of contention. What would have happened without Quang Duc's sacrifice? Perhaps an act of suicide protest would have eventually attracted comparable media attention and caused comparable political repercussions. Perhaps someone would have eventually combined suicide protest with death by fire. Conceivably, though, the history of suicide protest would have been very different without Quang Duc.

By the end of 1970, suicide protest had been adopted in sixteen countries since Quang Duc's immolation. It had also been deployed for many causes unrelated to Vietnam and U.S. foreign policy. The potential modularity of suicide protest had been realized, which was crucial to ensure its persistence in the long run. After all, the Vietnamese conflict ended when the North conquered the South in 1976; the ensuing suppression of Buddhism led to further immolations by monks and nuns, but these actions all but disappeared as the communist regime strengthened its grip. In most countries suicide protest remained an idiosyncratic act with minimal consequences. In a few countries, by contrast, the tactic became a vital element in the repertoire - still rare, but having major consequences. A prime example is South Korea. In 1970, Chun Tae-il, a worker in the garment industry, set himself on fire to protest against violations of the labor law (Cho 2003). His action became a model for trade unionists and leftist students, with at least 88 killing themselves in the next two decades (Kim 2002, 2008; Korea Association 1997; Park 1994, 2004). At the global scale, the frequency of suicide protest has not reverted to the minimal level of the 1950s (Biggs 2005: 183). The tactic has entered the global repertoire of contention in the sense that many millions of people, in many diverse cultures, know it as a tactic.

Needless to say, the incidence and impact of suicide protest has varied across societies. Systematic analysis of this variation is a task for future inquiry. Two lines of investigation are promising. One pertains to political opportunities. Suicide protest should be least effective in a totalitarian regime, because it can suppress information. At the other end of the spectrum, the tactic is less effective and less legitimate in democratic systems, because most people will view it as too extreme, given the plentiful opportunities for political voice. We therefore expect suicide protest to be most prevalent in political systems that lie between these two extremes. Aside from political opportunities, culture is obviously important: the challenge is to identify which aspects have explanatory power. One candidate is a tradition of self-inflicted suffering - a much wider category than suicide protest as defined here-recorded in political history or extolled in sacred texts. At a more basic level, the custom of cremation helps to explain why death by fire inspires reverence rather than revulsion. Notwithstanding such important variations, one central finding of this article is that suicide protest - by fire though not by seppuku - has been adopted in diverse cultural traditions.

What does this tactic reveal about the repertoire of contention? In my reformulation of Tilly's insight, adoption is far more likely than invention. By implication, protesters some- 
times do not use a tactic that would be feasible, legitimate, and potentially effective because they have not seen it used. Suicide protest is a limiting case, of course, because it entails the ultimate sacrifice. This makes its adoption from 1963 onward all the more remarkable: some individuals killed themselves for a cause because they had seen it done by someone else. The sudden increase in the rate of suicide protest cannot be explained by structural changes in feasibility, effectiveness, or legitimacy, because such transformations worked gradually. To take a very concrete example, setting oneself alight in a public place - when the state wishes to prevent it - depended on the availability of flammable liquids (like kerosene and petrol), which was the result of long-term economic development. But fuel was scarcely more available in 1963 than 1962. Sudden change runs counter to Tilly's (2008: 4) claim that "performances change incrementally."

Suicide protest can be added to the lengthy catalog of practices, ideas, and institutions that have been subject to crossnational diffusion in the twentieth century (Meyer et al. 1997). Viewed in this wider perspective, suicide protest is significant because it is not amenable to the usual explanations. No group of professionals or experts took it up; cultural theorization of similarities was not apparent; multinational corporations or international nongovernmental organizations were not involved; isomorphism among national states was not directly implicated..$^{25}$ It is certainly not the case that suicide protest has become normative within the world polity; it is a deviant act, even in countries where it is most prevalent. Crossnational diffusion is primarily explained by the news media. Millions of people can be moved by a report (especially with an image) of someone dying as an act of protest, even when the collective cause is distant or alien. A few of those people will adopt the tactic for themselves. Paradoxically, suicide protest is extremely simple, for it demands no technical expertise or collective coordination. All it requires is one person with unimaginable courage.

This article has highlighted the modern state's unwillingness to inflict cruel public punishment on those it claims to rule. Suicide protest is only one of a family of tactics that employ what could be called "communicative suffering" (Biggs 2003). Another is the hunger strike. Suffering need not be self-inflicted. In some cases, protesters deliberately provoke violence by local authorities in order to erode the legitimacy of rule. This was done skillfully by Indians in the British Empire in the 1920s and 1930s, and by blacks in the American South in the 1960s (Biggs 2003; McAdam 1996). When reported by the media, scenes of peaceful protesters being brutally attacked gained sympathetic attention from distant audiences. Less obviously related are protest actions that cause disruption only because the authorities have more to lose by deploying violence. When protesters chain themselves to railroad tracks to obstruct the transportation of nuclear waste, for example, their action presupposes the fact that they will not be harmed. The historical transformations that made such tactics effective deserve further investigation.

There are two methodological implications for research on protest events. First, we should reconstruct the genealogies of protest tactics by distinguishing among invention, adoption, and repetition. Identifying whether there was actually a connection between one instance of a tactic and another - whether by adoption or by repetition - is the crucial empirical challenge. In the case of suicide protest, repetition can be ruled out. Adoption has been identified from the explicit testimony of protesters, from the signature method of fire, and from the overall frequency of events. Reconstructing the genealogy of a tactic requires intensive historical investigation of protest events (exemplified by Traugott 2010), beyond classification and enumeration. This article has shown that almost all acts of suicide protest in the past halfcentury belong to a single lineage. Future research should determine whether this finding holds for other tactics. Take, for example, the sit-down strike, which emerged on a massive scale in Europe and North America in the 1920s and 1930s (Laba 1991: 102). Did these sitdown strikes constitute a series of adoptions and repetitions descended from a single invention, as the concept of repertoire implies? Or were they invented numerous times in response to the same structural changes? The genealogical method could be generalized 
beyond tactics to frames, such as the demand for "equal rights" which has proliferated in Western countries since the 1960s. Even the "social movement" itself may be an idea whose single lineage extends over two centuries. Reconstructing genealogies of ideas is now more feasible with the digitization of historical corpora.

The second methodological implication is the need for a global perspective on protest events (e.g., Silver 2003). The literature is dominated - for understandable reasons-by studies of a single wave of mobilization, a single social movement, or protest events in a single country. The concept of repertoire is valuable for drawing attention to deeper currents beneath the waves, currents that transcend differences among social movements and traverse boundaries between national states. This article demonstrates, I hope, the potential of tracing the diffusion of one particular protest tactic across different movements and cultures, over a period of many decades. One happy consequence is the decentering of Europe and North America. Broadening the scope of investigation is not easy and gathering evidence in other languages poses formidable difficulties. Some sociologists insist that it is not legitimate to consider action beyond its immediate local context. One thing is certain, however: people can be inspired by the actions of others, no matter how far removed in distance or culture. The horizon of our research must be as wide.

\section{NOTES}

${ }^{1}$ The death of ten Irish Republican hunger strikers in 1981 is salient for many readers, but this is exceptional. In 1923 a mass hunger strike of 7,619 Republicans incarcerated by the Irish Free State ended in two deaths; the remainder gave up.

2 Since 1973, standard questions ask whether the respondent has ever signed a petition, attended a lawful demonstration, and so forth (e.g., Biggs 2013; Caren, Ghoshal, and Ribas 2011).

${ }^{3}$ Given that repetition is more likely than adoption (and that adoption becomes more likely with social and geographical proximity), the mobility of experienced individuals will often be important in the diffusion of protest tactics: they repeat the tactic in their new location, which makes it more readily adopted by local others.

${ }^{4} \mathrm{He}$ was strangely unaware of thousands of hunger strikes by suffragettes and Irish Republicans in the British Isles, only a few decades before.

${ }^{5}$ According to Traugott (2010), the tradition of barricades endured in France despite the complete lack of use between 1652 and 1789

${ }^{6}$ Exceptionally, an Indian student who survived setting himself on fire in 1991 attempted it again in 1993, though the second time was more theatrical (Agence France-Presse, September 21).

${ }^{7}$ There are two exceptions from the data below. When political prisoners were released after the overthrow of the Diem regime, a maid killed herself claiming that she had promised to sacrifice her life in return for the freedom of Buddhist prisoners; a monk did the same shortly afterwards (NYT, December 1, 1963, p. 9; January 15, 1964, p. 5).

${ }^{8}$ Supernatural intermediation was also hinted by his promise "to help you gentlemen from the nether world."

9 Ohara's death was not reported contemporaneously in NYT or Times, though it was mentioned long afterwards (NYT, June 3, 1924, p. 16).

${ }^{10}$ This was a forerunner of the global diffusion of "human rights" that occurred in the second half of the twentieth century (Meyer et al. 1997).

${ }^{11}$ Aside from Ohara in 1891, individual cases are reported in some detail from 1871 (Pinguet 1984: 195) and 1880 (Seward 1968: 97). Supposedly, 40 officers killed themselves to protest against the settlement with China in 1895 (Chamberlain 1905: 220, repeated in Pinguet 1984: 211; Bargen 2006: 52), but there is no source and the number is implausible.

${ }^{12}$ The Times is published only six days a week. Its weekly companion, The Sunday Times, awaits digitization.

${ }^{13}$ Search string: immolat* or "himself to death" or "herself to death" or "themselves to death" or "kill* himself" or "kill* herself" or "kill* themselves" or (suicid* and protest*) or "suicide by fire" or "himself on fire" or "herself on fire" or "themselves on fire."

${ }^{14}$ Drygas 1991; Forest 1978: 31-35; The Hindu, February 12, 1965, p. 1; Kwiet 1984: 147; Radio Praha 2004; Ramaswamy 1997: 233, 271-72; Vardys 1978: 173; Welch 1967: 327. One case reported by NYT in 1992 has also been classified under other sources, given that it was not found by searching within the period.

${ }^{15}$ Some information on Siwiec filtered through to the West, but it could be dismissed as incredible (New Statesman, February 14 and 21, 1969, pp. 179, 257).

${ }^{16}$ Computed using negative binomial regression with mean dispersion, taking exposure as urban population. A binary variable for 1962-70 has two-sided $p<.001$; excluding South Vietnam, $p=.005$.

${ }^{17}$ The table excludes seven acts of suicide protest where the method is unknown. Even with such small numbers, method and period are strongly associated (chi-square $=72, p<.001$ ).

${ }^{18}$ As a threat, this is not included in my data. 
${ }^{19}$ Aoshima's wife also killed herself, but she wrote simply, "I must act as a soldier's wife should." As a case of following into death (Fisch 2005), it does not enter my data.

${ }^{20}$ A gory picture of Mishima's severed head did appear, however, in Life magazine and the Japanese press.

${ }^{21}$ American clergymen used the image of Quang Duc on fire for a full-page advertisement, headed "We, too, protest" (NYT, June 27, 1963, p. 21).

${ }^{22}$ An earlier suicide protest was reported in the USSR, ostensibly- "according to Soviet sources"- because the authorities refused to allow the individual to fight for communism in Vietnam (NYT, April 12, 1966, p. 7). This sounds like a convenient fiction to conceal antigovernment protest.

${ }^{23}$ Early in 1966, 77 percent of Americans were willing to continue the war even if that meant bombing North Vietnam (Verba et al. 1967: 320).

${ }^{24}$ Palach himself mentioned no model for his action. It is tempting to interpret his immolation as drawing a symbolic parallel between Soviet imperialism in Eastern Europe and American imperialism in Southeast Asia.

${ }^{25}$ Isomorphism among states - as with the decline of cruel public punishment-has indirectly structured the circumstances that make suicide protest feasible.

\section{REFERENCES}

Andrews, Kenneth T., and Michael Biggs. 2006. "The Dynamics of Protest Diffusion: Movement Organizations, Social Networks, and News Media in the 1960 Sit-ins." American Sociological Review 71(5): $752-77$.

Bargen, Doris G. 2006. Suicidal Honor: General Nogi and the Writings of Mori Ogai and Natsume Soseki. Honolulu: University of Hawai'i Press.

Barranco, José, and Dominique Wisler. 1999. "Validity and Systematicity of Newspaper Data in Event Analysis." European Sociological Review 15(3): 301-22.

Bauer, Sándor. [1969] 2010. “Dopisy Sándora Bauera rodičům, kamarádům a spolužákům na rozloučenou před sebeupálením.” Pp. 407-08 in Za vaši i naši svobodu, edited by Adam Hradilek. Prague, Czech Republic: Torst a Ústav pro studium totalitních režimů.

Benn, James A. 2007. Burning for the Buddha: Self-Immolation in Chinese Buddhism. Honolulu: University of Hawai'i Press.

Beissinger, Mark R. 2007. "Structure and Example in Modular Political Phenomena: The Diffusion of Bulldozer/Rose/Orange/Tulip Revolutions." Perspectives on Politics 5(2): 259-76.

Biggs, Michael. 2003. "When Costs are Beneficial: Protest as Communicative Suffering." Sociology Working Papers, University of Oxford, no. 2003/04.

. 2005. "Dying without Killing: Self-Immolations, 1963-2002." Pp. 173-208 in Making Sense of Suicide Missions, edited by Diego Gambetta. Oxford, UK: Oxford University Press.

. 2013. "The Mismeasurement of Strikes and the Distortion of Protest Trends: Evidence from Britain in the 1980s and 1990s." Sociology Working Papers, University of Oxford, no. 2013/03.

Bourgeois, Marc. 1969. "Suicides par le feu à la manière des bonzes." Annales Médico-Psychologiques, May 19, pp. 116-127.

Braun, Robert. 2011. "The Diffusion of Racist Violence in the Netherlands: Discourse and Distance." Journal of Peace Research 48(6): 753-66.

Braun, Robert, and Ruud Koopmans. 2010. "The Diffusion of Ethnic Violence in Germany: The Role of Social Similarity.” European Sociological Review 26(1): 111-23.

Browne, Malcolm W. 1965. The New Face of War: A Report on a Communist Guerrilla Campaign. London: Cassell. . 1993. Muddy Boots and Red Socks: A Reporter's Life. New York: Random House.

Brodrick, Alan Houghton. 1942. Little China: The Annamese Lands. London: Oxford University Press.

Caren, Neal, Raj Andrew Ghoshal, and Vanesa Ribas. 2011. "A Social Movement Generation: Cohort and Period Trends in Protest Attendance and Petition Signing." American Sociological Review 76(1): $125-51$.

Chabot, Sean. 2000. "Transnational Diffusion and the African American Reinvention of Gandhian Repertoire." Mobilization 5(2): 201-16.

Chamberlain, Basil Hall. 1905. Things Japanese: Being Notes on Various Subjects Connected with Japan, 5th ed. London: John Murray.

Chapuis, Oscar. 1995. A History of Vietnam from Hong Bang to Tu Duc. Westport, CT: Greenwood Press.

Chân Không, Sister. 1993. Learning True Love: How I Learned and Practiced Social Change in Vietnam. Berkeley, CA: Parallax Press. 
Chevers, Norman. 1870. A Manual of Medical Jurisprudence for India. 3rd ed. Calcutta, India: Thacker, Spink and Co.

Ci Xing Temple. 1958. Du-lun Chanshi Shiji (The Activities of Du-lun Zen Master). Hong Kong: Fojiao Chubanshe.

Cho Young-rae. 2003. A Single Spark: A Biography of Chun Tae-il. Seoul, South Korea: Han Chul-hee.

Chong, Chin-Sok. 1987. The Korean Problem in Anglo-Japanese Relations, 1904-1910: Ernest Thomas Bethell and His Newspapers: The Daehan Maeil Sinbo and the Korea Daily News. Seoul, South Korea: NANAM Publications.

Crosby, Kevin, Joong-oh Rhee, and Jimmie Holland. 1977. "Suicide by Fire: A Contemporary Method of Political Protest.” International Journal of Social Psychiatry 23(1): 60-69.

Drygas, Maciej J. 1991. Ustyszcie Mój Krzyk (Hear My Cry). Poland: Studio Filmowe Logos and Zespól Filmowy "Zodiak." Film.

Du Bois, W. E. B. 1943. "As the Crow Flies.” New York Amsterdam Star News, March 13, p. 10.

Durkheim, Emile. [1897] 1952. Suicide: A Study in Sociology. New York: Free Press.

Earl, Jennifer, Andrew Martin, John D. McCarthy, and Sarah A. Soule. 2004. "The Use of Newspaper Data in the Study of Collective Action." Annual Review of Sociology 30: 65-80.

Eisler, Jerzy. 2010. “Polsko v Roce 1968 a Pražské Jaro.” Pp. 201-19 in Za vaši i naši svobodu, edited by Adam Hradilek. Prague, Czech Republic: Torst a Ústav pro studium totalitních režimů.

Elias, Norbert. [1939] 1994. The Civilizing Process: The History of Manners. Oxford, UK: Blackwell.

Elosegi, Joseba. 1971. Quiero Morir Por Algo. Bordeaux, France: Imprimeries Delmas.

Finch, Michael. 2002. Min Yŏng-Hwan: A Political Biography. Honolulu: University of Hawai'i Press.

Fisch, Joerg. 2005. Burning Women: A Global History of Widow-Sacrifice from Ancient Times to the Present. Oxford, UK: Seagull Books.

Fligstein, Neil, and Doug McAdam. 2011. "Toward a General Theory of Strategic Action Fields." Sociological Theory 29(1): 1-26.

Forest, James H. 1978. The Unified Buddhist Church of Vietnam: Fifteen Years for Reconciliation. Alkmaar, Netherlands: International Fellowship for Reconciliation.

Foucault, Michel. [1975] 1979. Discipline and Punish: The Birth of the Prison. New York: Vintage Books.

Franzosi, Roberto. 1987. "The Press as a Source of Socio-Historical Data: Issues in the Methodology of Data Collection from Newspapers." Historical Methods 20(1): 5-15.

Fusé, Toyomasa. 1980. "Suicide and Culture in Japan: A Study of Seppuku as an Institutionalized Form of Suicide." Social Psychiatry 15(2): 57-63.

Gambetta, Diego. 2005. "Can We Make Sense of Suicide Missions?” Pp. 259-99 in Making Sense of Suicide Missions, edited by Diego Gambetta. Oxford, UK: Oxford University Press.

Gatrell, V. A. C. 1994. The Hanging Tree: Execution and the English People, 1770-1868. Oxford, UK: Oxford University Press.

Geertz, Clifford. 1980. Negara: The Theatre State in Nineteenth Century Bali. Princeton, NJ: Princeton University Press.

Giac Duc, Thich. 1986. "Buddhists and Catholics." Pp. 39-42, 134-146 in Portrait of the Enemy, edited by David Chanoff and Doan Van Toai. New York: Random House.

Glennon, John P., Edward C. Keefer, and Louis J. Smith. 1991. Foreign Relations of the United States, 1961-1963, vol. 3, Vietnam: January-August 1963. Washington, DC: United States Government Printing Office.

Grewal, J. S. 1990. The New Cambridge History of India, vol. II.3, The Sikhs of the Punjab. Rev. ed. Cambridge, UK: Cambridge University Press.

Grojean, Olivier. 2007. "Violence Against the Self: The Case of a Kurdish Non-Islamist Group." Pp. 105-120 in The Enigma of Islamist Violence, edited by Amélie Blom, Laetitia Bucaille, and Luis Martinez. London: C. Hurst and Co.

- 2008. "La cause kurde, de la Turquie vers l'Europe: Contribution à une sociologie de la transnationalisation des mobilisations." Ph.D. dissertation, Ecole des Hautes Etudes en Sciences Sociales, Paris, France.

Hahn, Arnold. 1936. Vor den Augen der Welt! Warum starb Stefan Lux? Sein Leben-seine Tat—seine Briefe. Prague, Czech Republic: Verlag Cechoslovakische Liga Gegen den Antisemitismus.

Hassler, Alfred. 1970. Saigon, U.S.A. New York: Richard W. Baron.

Hearn, Lafcadio. 1894. Glimpses of Unfamiliar Japan. Vol. 2. London: Osgood, McIlvaine.

Hill, Samuel Charles. 1914. Yusuf Khan: The Rebel Commandant. London: Longmans, Green and Co.

Hirobe, Izumi. 2001. Japanese Pride, American Prejudice: Modifying the Exclusion Clause of the 1924 Immigration Act. Stanford, CA: Stanford University Press. 
Hope, Marjorie. 1967. "The Reluctant Way: Self-Immolation in Vietnam.” The Antioch Review 27(2): 149-163.

Hull, David L. 1988. Science as a Process: An Evolutionary Account of the Social and Conceptual Development of Science. Chicago: University of Chicago Press.

India, Department of Archaeology. 1953. Annual Reports on Indian Epigraphy for the Years 1939-40 to 1942-43. Calcutta, India: Government of India Press.

Jasper, James M., and Jane D. Poulsen. 1995. "Recruiting Strangers and Friends: Moral Shocks and Social Networks in Animal Rights and Anti-Nuclear Protests." Social Problems 42(4): 493-512.

Joiner, Charles A. 1964. "South Vietnam's Buddhist Crisis: Organization for Charity, Dissidence, and Unity." Asian Survey 4(7): 915-28.

Jones, Howard. 2003. Death of a Generation: How the Assassinations of Diem and JFK Prolonged the Vietnam War. Oxford, UK: Oxford University Press.

Kahin, George McTurnan. 1987. Intervention: How America Became Involved in Vietnam. New York: Knopf.

Ketchley, Neil F. 2014 in press. "“The Army and the People Are One Hand!' Fraternization and the 25th January Egyptian Revolution." Comparative Studies in Society and History 56(1).

Kim, Hyojoung. 2002. "Shame, Anger, and Love in Collective Action: Emotional Consequences of Suicide Protest in South Korea, 1991." Mobilization 7(2): 159-176.

. 2008. "Micromobilization and Suicide Protest in South Korea, 1970-2004." Social Research 75(2): 543-78.

Koo, Hagen. 2001. Korean Workers: The Culture and Politics of Class Formation. Ithaca, NY: Cornell University Press.

Koopmans, Ruud. 2004. "Movements and Media: Selection Processes and Evolutionary Dynamics in the Public Sphere." Theory and Society 33(3-4): 367-91.

- 2005. "The Missing Link between Structure and Agency: Outline of an Evolutionary Approach to Social Movements." Mobilization 10(1): 17-33.

Koopmans, Ruud, and Susan Olzak. 2004. "Discursive Opportunities and the Evolution of Right-Wing Violence in Germany." American Journal of Sociology 110(1): 198-230.

Korea Association of Bereaved Families for Democracy and Korean Council for Democratic Martyrs. 1997. Sal-aseo Mannarira (We Shall Meet Alive). n.p.

Krishnan, K. G. 1983. “On Self-Immolation from Inscriptions.” Pp. 90-96 in Self-Immolation in Tamil Society, edited by N. Subrahmanian. Madurai, India: International Institute of Tamil Historical Studies.

Kwiet, Konrad. 1984. "The Ultimate Refuge: Suicide in the Jewish Community under the Nazis." Leo Baeck Institute: Year Book XXIX. London: Secker and Warburg.

Laba, Roman. 1991. The Roots of Solidarity: A Political Sociology of Poland's Working-Class Democratization. Princeton, NJ: Princeton University Press.

Lester, David. 2005. "Suicide and the Chinese Cultural Revolution." Archives of Suicide Research 9(1): 99-104.

McAdam, Doug. 1983. "Tactical Innovation and the Pace of Insurgency." American Sociological Review 48(6): 735-54.

. 1996. "The Framing Function of Movement Tactics: Strategic Dramaturgy in the American Civil Rights Movement.” Pp. 338-56 in Comparative Perspectives on Social Movements, edited by Doug McAdam, John D. McCarthy, and Mayer N. Zald. Cambridge, New York: Cambridge University Press.

McAdam, Doug, and Dieter Rucht. 1993. "The Cross-National Diffusion of Movement Ideas." Annals of the American Academy of Political and Social Sciences 528(1): 56-74.

McCammon, Holly J. 2003. "'Out of the Parlors and into the Streets': The Changing Tactical Repertoire of the U.S. Women's Suffrage Movements." Social Forces 81(3): 787-818.

McCarthy, John D., Clark McPhail, and Jackie Smith. 1996. "Images of Protest: Dimensions of Selection Bias in Media Coverage of Washington Demonstrations, 1982 and 1991." American Sociological Review 61(3): 478-99.

Makela, Lee Arne. 1972. "Japanese Attitudes toward the United States Immigration Act of 1924." Ph.D. dissertation, Department of History, Stanford University.

Maney, Gregory M., and Pamela E. Oliver. 2001. "Finding Collective Events: Sources, Searches, Timing." Sociological Methods and Research 30(2): 131-169.

Mani, Lata. 1998. Contentious Traditions: The Debate on Sati in Colonial India. Berkeley, CA: University of California Press. 
Meyer, John W., John Boli, George M. Thomas, and Francisco O. Ramirez. 1997. "World Society and the Nation-State." American Journal of Sociology 103(1): 144-181.

Mishima, Yukio. 1961. "Patriotism." Pp. 93-118 in Death in Midsummer and Other Stories. New York: New Directions.

Morrison Welsh, Anne. 2003. "The Ultimate Protest." Pp. 150-155 in Patriots: The Vietnam War Remembered from All Sides, edited by Christian G. Appy. London: Viking.

Mueller, Carol. 1997. "International Press Coverage of East German Protest Events, 1989." American Sociological Review 62(5): 820-32.

Myers, Daniel J. 2000. "The Diffusion of Collective Violence: Infectiousness, Susceptibility, and Mass Media Networks." American Journal of Sociology 106(1): 173-208.

Myers, Daniel J., and Beth Schaefer Caniglia. 2004. "All the Rioting That's Fit to Print: Selection Effects in National Newspaper Coverage of Civil Disorders, 1968-1969." American Sociological Review 69(4): 519-43.

Nathan, John. 1974. Mishima: A Biography. London: Hamish Hamilton.

Oka, Takashi. 1966. "Buddhism as a Political Force." Institute of Current World Affairs Newsletter, TO25.

Oliver, Pamela E., and Gregory Maney. 2000. "Political Processes and Local Newspaper Coverage of Protest Events: From Selection Bias to Triadic Interactions." American Journal of Sociology 106(2): 463-505.

Oliver, Pamela E., and Daniel J. Myers. 1999. "How Events Enter the Public Sphere: Conflict, Location, and Sponsorship in Local Newspaper Coverage of Public Events.” American Journal of Sociology 105(1): 38-87.

Olzak, Susan. 1989. "Analysis of Events in the Study of Collective Action.” Annual Review of Sociology 15: 119-141.

- 2006. The Global Dynamics of Racial and Ethnic Mobilization. Stanford, CA: Stanford University Press.

Ortiz, David G., Daniel J. Myers, Eugene N. Walls, and Maria-Elena D. Diaz. 2005. "Where Do We Stand with Newspaper Data?" Mobilization 10(3): 397-419.

Park, Chang-Won. 2005. "Korea.” Pp. 289-91 in Encyclopedia of Cremation, edited by Douglas J. Davies and Lewis H. Mates. Aldershot, UK: Ashgate Publishing.

Park, Byeong-chul. 1994. "Political Suicide among Korean Youth." Bulletin of Concerned Asian Scholars 26(1-2): 66-81.

Park, B.C. Ben. 2004. "Sociopolitical Contexts of Self-Immolations in Vietnam and South Korea." Archives of Suicide Research 8(1): 81-97.

Phillips, Michael R., Huaqing Liu, and Yanping Zhang. 1999. "Suicide and Social Change in China." Culture, Medicine, and Psychiatry 23(1): 25-50.

Pinguet, Maurice. [1984] 1993. Voluntary Death in Japan. Cambridge, UK: Polity Press.

Radio Praha. 2004. Jan Palach, 16.1.1969. Retrieved May 1, 2004 (http://archiv.radio.cz/palach99/ eng/).

Rainer, János M. 2010. “Mad’arsko a Okupace Československa v roce 1968.” Pp. 367-78 in Za vaši $i$ naši svobodu, edited by Adam Hradilek. Prague, Czech Republic: Torst a Ústav pro studium totalitních režimů.

Ramaswamy, Sumathi. 1997. Passions of the Tongue: Language Devotion in Tamil India, 1891-1970. Berkeley, CA: University of California Press.

Rejali, Darius M. 1994. Torture and Modernity: Self, Society, and State in Modern Iran. Boulder, CO: Westview Press.

Rips, Elijahu. 2010. "Rozhovor vedli Michael Stoilova a Adam Hradilek.” Pp. 167-185 in Za vaši i naši svobodu, edited by Adam Hradilek. Prague, Czech Republic: Torst a Ústav pro studium totalitních režimů.

Rogers, Everett. 1962. Diffusion of Innovations. New York: Free Press of Glencoe.

. 2003. Diffusion of Innovations. 5th ed. New York: Free Press.

Scalmer, Sean. 2011. Gandhi in the West: The Mahatma and the Rise of Radical Protest. Cambridge, UK: Cambridge University Press.

Scott-Stokes, Henry. 1975. The Life and Death of Yukio Mishima. London: Peter Owen.

Searle, John R. 1976. “A Classification of Illocutionary Acts.” Language in Society 5(1): 1-23.

Seward, Jack. 1968. Hara-kiri: Japanese Ritual Suicide. Rutland, VT: Charles E. Tuttle.

Sewell, William H., Jr. 1990. "Collective Violence and Collective Loyalties in France: Why the French Revolution Made a Difference." Politics and Society 18(4): 527-52. 
Shibata, Shingo. 1976. Phoenix: Letters and Documents of Alice Herz: The Thought and Practice of a Modern-Day Martyr. Amsterdam, Netherlands: B. R. Grüner.

Shillony, Ben-Ami. 1973. Revolt in Japan: The Young Officers and the February 26, 1936 Incident. Princeton, NJ: Princeton University Press.

Silver, Beverly J. 2003. Forces of Labor: Workers' Movements and Globalization since 1870. Cambridge, UK: Cambridge University Press.

Snow, David A., E. Burke Rochford, Steven K. Worden, and Robert D. Benford. 1986. "Frame Alignment Processes, Micromobilization, and Movement Participation." American Sociological Review 51(4): 464-81.

Soule, Sarah A. 1997. "The Student Divestment Movement in the United States and the Shantytown: Diffusion of a Protest Tactic." Social Forces 75(3): 855-83.

. 1999. "The Diffusion of an Unsuccessful Innovation: The Case of the Shantytown Protest Tactic." Annals of the American Academy of Political and Social Science 566(1): 120-131.

Sreeramulu, B. 1988. Socio-Political Ideas and Activities of Potti Sriramulu. Bombay, India: Himalaya Publishing House.

Stark, Rodney. 1996. The Rise of Christianity. Princeton, NJ: Princeton University Press.

Steinbach, Alice. 1995, "The Sacrifice of Norman Morrison.” Baltimore Sun, July 30, pp. 1K, 4K, 5K.

Tarde, Gabriel de. [1895] 1903. The Laws of Imitation. 2nd ed. New York: Henry Holt.

Tarrow, Sydney. 1998. Power in Movement: Social Movements, Collective Action, and Politics. 2nd ed. New York: Cambridge University Press.

. 2010. "Dynamics of Diffusion: Mechanisms, Institutions and Scale Shift." Pp. 204-19 in The Diffusion of Social Movements, edited by Rebecca Kolins Givan, Sarah A. Soule, and Kenneth M. Roberts. New York: Cambridge University Press.

Tilly, Charles. 1977. "Getting It Together in Burgundy, 1675-1975." Theory and Society 4(4): 479-504. . 1995. Popular Contention in Great Britain, 1758-1834. Cambridge, MA: Harvard University Press.

. 2008. Contentious Performances. Cambridge, UK: Cambridge University Press.

Tocqueville, Alexis de. [1840] 2000. Democracy in America. Vol. 2. Chicago: University of Chicago Press.

Tod, James. 1832. Annals and Antiquities of Rajast'han or the Central and Western Rajpoot States of India. Vol. 2. London: Smith, Elder.

Topmiller, Robert. 2002. The Lotus Unleashed: The Buddhist Peace Movement in South Vietnam, 19641966. Lexington, KY: University Press of Kentucky.

Traugott, Mark. 2010. The Insurgent Barricade. Berkeley: University of California Press.

Treptow, Kurt W. 1989. "The Winter of Despair: Jan Palach and the Collapse of the Prague Spring." Ukrainian Quarterly 45(1): 30-47.

Vardys, V. Stanley. 1978. The Catholic Church, Dissent, and Nationality in Soviet Lithuania. Boulder, CO: East European Quarterly.

Verba, Sidney, Richard A. Brody, Edwin B. Parker, Norman H. Nie, Nelson W. Polsby, Paul Ekman, and Gordon S. Black. 1967. "Public Opinion and the War in Vietnam." American Political Science Review 61(2): 317-33.

Welch, Holmes. 1967. The Practice of Chinese Buddhism, 1900-1950. Cambridge, MA: Harvard University Press.

Westermarck, Edward. 1908. "Suicide: A Chapter in Comparative Ethics.” Sociological Review 1(1): 12-33.

Woolley, John T. 2000. "Using Media-Based Data in Studies of Politics." American Journal of Politics 44(1): 156-173.

Wulff, Erich. 1963. "The Buddhist Revolt: Diem's New Opponents Deserve US Support.” New Republic, August 31, pp. 11-14. 